\title{
BOOK DEPARTMENT
}

\section{NOTES}

Abbott, Edith. Women in Industry. Pp. xxii, 408. Price, $\$ 2.00$. New York: D. Appleton \& Co., 1909 .

The title is misleading, for the book deals not with women in industry, but with the history of the industrial activity of women in the United States. No attempt whatever is made to discuss the present problems connected with women in industry. There is no reference to legislation, nor to the conditions under which women work. The book, however, is exceedingly valuable in establishing beyond question two important points and replacing two threadbare theories. In the first place, the author proves that men alone were not the first in the factory system in the United States, for, in the earliest factories, women employees played a leading part. In the second place, she shows that women have played an exceedingly important part in industry from the beginning of the nineteenth century, and, therefore, the general statement that women have been coming into industry only recently is unfounded. The book is ably written, with copious references to source material, and presents in a forceful manner a new view of the historical significance of women in industry.

Abbott, F. F. Society and Politics in Ancient Rome. Pp. x, 267. Price, \$1.25. New York: Charles Scribner's Sons, Igog.

A collection of essays on various phases of Roman social life. Excellent from a literary standpoint and illustrative of social conditions and public questions in Rome. Should be particularly interesting to any' student of the classics.

Aveling, H. F., and others. The History Sheet or Case-Paper System. Pp. xii, I67. Price, 2s. London: P. S. King \& Son, I909.

The History Sheet or Case-Paper System is a little book containing five papers read at Poor Law Conferences in 1903, 1904 and 1907, with an introduction by Sir William Chance and a few appendices. The subject, which may not be obvious to a casual American reader of the title, is the advantage of keeping records of applicants for relief in such a way as to have the history of each one accessible to the relieving officer.

It appears that the usual method consists in merely entering applications in a book in chronological order, and "when this book is not indexed it depends entirely upon the memory of the relieving officer how much of the applicant's past history is brought before the guardians. When a new relieving officer succeeds to the work, the cases to him are all new."

The argument for the superiority of a method by which a continuous (449) 
record is kept of each applicant and his family is necessarily elementary. The most interesting features of the book are the apparent absence of all difficulty in distinguishing between the "deserving" and "undeserving" poor; the citation of stories with quite a different application from the one which seems to us most patent; and the disposition to see, in evidences that pauperism is "hereditary," merely an interesting historical fact rather than a commentary on the way in which the fathers and grandfathers of the present generation of "paupers" have been treated.

Barnett, G. E. The Printers-A Study in American Trade Unionism. P. vii, 387. Price, \$1.50. Cambridge, Mass.: American Economic Association, Igog.

This is a work of unusual interest. In the words of the author, it aims "to give a complete description of an American trade union." It is a study in connected form of the history, the structure, the activities, and the policy of the American typographical unions-in effect-of the International Typographical Union. A fair, impartial, and restrained mode of treatment characterizes the whole book-the author has been content to describe, he skilfully avoids even the appearance of bias or interpretation. The technique of the trade has been dealt with in an admirable manner, and he has eluded for himself and his readers most of those pitfalls which lie in the technical terms of the quasi-mechanical printing trade.

The historical method has been followed, with free and full quotation from official papers and from hitherto unpublished records of the International Union. The work divides itself naturally into three partsHistory and Government, Insurance and Trade Regulations, The Enforcement of Trade Regulations. The greatest interest centers easily about the trade regulations and the varions means and policies adopted from time to time with a view to enforcing them. He fully describes the truly remarkable way in which labor-saving devices and machines have been introduced into the trade and assimilated without seriously disorganizing it. In that chapter in which he has dealt with the problem of irregularity of employment, the cohesive power and fraternal spirit of the union is seen at its best. To the work is appended a fairly complete bibliography, some copies of the minutes of early organizations, and a tabulation of the number and membership of the local unions of the International from 1853 to the present time.

Bellom, M. Les Lois d'Assurance Ouvric̀re à l'Etranger. Pp. 588. Price, I5f. Paris: A. Rousseau, Igog.

The book contains a compilation of European laws relating to sickness, accidents and invalidity. Extracts are given together with the latest amendments to the laws of Germany, Denmark, Hungary, Belgium, Russia, Spain, Italy and Switzerland. The book should prove of value to students of insurance legislation.

Blggle, J. Biggle Garden Book. Pp. 184. Price, 50 cents. Philadelphia: W. Atkinson Company. 
Bryce, James. The Hindrances to Good Citizenship. Pp. 138. Price, \$1.15. New Haven: Yale University Press, 1909.

Indolence explains our large "stay-at-home vote." It is the most common failing of the American elector. Less widely felt is the influence of selfish personal interest, most men easily convince themselves that what is for their interest is for the public interest-hence the protective tariff, corruption in public contracts and the corrupt use of money in elections. The influence of personal advantage is the most corrupting in present-day politics. It is a problem that becomes of increasing importance as the wealth of nations increases, especially where increased wealth tends to bring with it an increase of class distinctions. The surest way to better political conditions is to educate the electors to a greater civic interest. There are also mechanical changes which can be of help, such as proportional representation, the initiative and referendum and laws regulating lobbying, the primaries and the elections. Yet it is from the heart and will of the citizen that all real and lasting improvements must proceed. All that Mr. Bryce writes is forceful and clear. These four lectures will be highly appreciated by all who sympathize with his judicial but still optimistic viewpoint.

Cabot, R. C. Social Service and the Art of Healing. Pp. ix, I92. Price, \$1.oo. New York: Moffat, Yard \& Co., 1909

This admirable little volume is written "to exemplify three forms of team work," $i$. e., the team work of doctor and social worker, of doctor and patient, and of doctor and the educator, the psychologist, the minister and the philanthropist. It describes the changes whereby medical, social and educational work are being drawn together for the good of the community. The doctor must become an educator. "Public health and the extermination of disease, that most fruitful cause of poverty, of misery, and of crime, are the ideals for which doctors and social workers are joining hands today." Vice, ignorance, overcrowding, sweatshops and poverty give the key to much of the sickness; on the other hand, poor nutrition, physical defects, alcoholism, tuberculosis and accidents give to the social worker the reason for much of the poverty, shiftlessness, vice and crime with which he must cope. Team work is necesary. The educator is realizing that he cannot cope with his problems alone. To neutralize the evils of a compulsory school requirement, the authorities are compelled to provide physical tests, school nurses, and medical attendance. Again, team work is required.

Dr. Cabot, at a recent conference on social service in the hospitals, held in New York, declared that at least two-fifths of the patients treated at the hospital and the hospital dispensary need more than mere medical or surgical care. This is the reason that eight trained social workers have been added to the staff of the Massachusetts General Hospital, in which Dr. Cabot is an assistant visiting physician.

Carpenter, C. W. Profit-Making in Shop and Factory Management. Pp. I46. New York: Engineering Magazine.

Persons in a position to know whereof they speak are quite sure that there 
is astonishing disorganization in manufacturing industry. Several books have been lately written telling how this disorganization may be eradicated and replaced by order and method. Of this class is this book by $\mathrm{Mr}$. Carpenter, present president of the Herring, Hall, Marvin Safe Company, and late president of the National Cash Register Company, which has been noted throughout the country as an exponent of excellent treatment of its employees. The book describes the actual methods which he has put into operation.

Carson, W. E. Mexico. Pp. xi, 439. Price, \$2.25. New York: Macmillan Company, roog.

Cohen, J. E. Socialism for Students. Pp. I53. Chicago: Charles H. Kerr \& Company, I9Io.

In spite of occasional dogmatic assertions and misstatements of the "other side," this little book is a clear and serviceable presentation of socialism for non-socialists.

Colby, F. M. (Ed.). International Year Book. Pp. 776. New York: Dodd, Mead \& Co., 1909

The new International Year Book's compendium of the world's progress for the year 1908 , was issued early in 1909, and brings down to date a large number of subjects. The list of contributors is large, and the treatment of many questions in which there is rapid progress seems to be thoroughly up to date and of such a character as to make the book very desirable for any well equipped library.

Curtin, J. A. A Journey in Southern Siberia. Price, \$3.00. Boston: Little, Brown \& Co., rgog.

Davenport, E. Education for Efficiency. Pp. v, 184. Price, \$1.00. Boston: D. C. Heath \& Co., Igog.

In this little volume the author enthusiastically advocates universal education in its literal sense. But if education becomes truly universal, objectors argue, the washerwoman's daughter will not return to the tub, nor the ditcher's son to the ditch; we will have an army of officers, but no privates to do the fighting. The author answers this argument by showing that education of the right sort does not educate away from industry and the common walks of life. Merely admitting the "masses" to school does not constitute universal education, the schools must be actively fitted and adapted to the "masses."

Having demonstrated that industrial or vocational education is necessary, the author throws the whole weight of his influence against the establishment of separate industrial schools. Such schools train the operative rather than educate the citizen; they lose in breadth more than they gain in directness. But if the high schools delay longer in adding industrial cottrses, the industrial people will secede, and separate trade schoo!s will be established to the permanent detriment of our system. The latter part of the book show how agriculture, at least, may make its way into existing schools without detriment to other courses, but vastly to their advantage. 
Dearle, N. B. Problems of Unemployment in the London Building Trades.

Pp. xix, 195. Price, 3/6. London: Dent \& Co.

The author holds that changes in the demand for labor in the form of cyclical or trade depressions, seasonal and temporary changes over periods of less than a year, together with the failure to adjust the supply of labor to the demand for it, and the defects of "human nature," are responsible for unemployment as it appears in the London building trades. After a chapter carefully analyzing the extent of the building trades in London a discussion follows of the variations due to changes in business conditions over long periods of years. There is also an excellent chart showing these variations for the industries of London at large and for the building trades. According to this chart, the worst conditions in the recorded history of the trade have prevailed since 1900. Never before was unemploymnet so serious nor trade depression so prevalent.

After devoting an intervening chapter to a statement of the condition of the master builders, who, it is maintained, are short of work, the author further discusses and illustrates variations in unemployment and seasonal unemployment. The general, short irregularities in employment are largely due to the contract system of work, which does not insure stability for any one employer.

In discussing the remedies heretofore adopted for unemployment the author proposes first that the scope of trade union organization be made more general, and second, that a system of labor exchunges be orovided. The analysis of the working conditions presented in the first part of the book is most excellent, but the remedies proposed seem to the writer superficial.

Dole, C. F. The Ethics of Progress. Pp. vii, 398. Price, \$1.50. New York: T. Y. Crowell \& Co., I909.

Fisher, Irving. Report on National Vitality-Its Wastes and Conservation.

Pp. viii, 138. Washington: Govermment Printing Office, I909.

This pamphlet is a carefully prepared statistical brief dealing with the length of life and the factors which influence it; with the hindrance which low national vitality is to the development of national efficiency, and with personal, semi-public and state hygiene, the introduction of which will insure length of life and higher industrial efficiency. The report is a strong presentation of the possibilities of human life, and the opportunity which exists for its development and prolongation through sanitation, hygiene and the awakening of the social conscience. While not intended for the general public, the pamphlet will assuredly attract the attention and win the hearty commendation and co-operation of all scholars, students and specialists in this and kindred fields, and will lead to an added emphasis being laid upon the great importance of the conservation of national vitality.

Garcia, G. Leona Vicario, Heroina Insurgente. Pp. zio. Mexico: Museo Nacional de Arqueologia, Historia y Etnologia, rgro.

Students of Latin-American history owe a heavy debt of gratitude to the 
indefatigable Director of the Mexican National Museum of Archæology, History and Ethnology, Dr. Genaro Garcia. Not content with the excellent series of documents illustrative of Mexican colonial and constitutional history, Dr. Garcia is publishing a number of monographic studies dealing with notable figures in the history of Mexican independence. In this work on Leona Vicario the author has given us an account of the activities of one of the few women who figured in the revolutionary movement against Spain. As part of the work the author has reprinted a number of important documents relating to the events immediately preceding and following the declaration of Mexican independence.

Gibson, Thomas. The Cycles of Speculation. Pp. I87. Price, \$1.50. New York: Moody Corporation.

This little rolume is supplementary to Mr. Gibson's earlier book, "The Pitfalls of Speculation" and deals with special problems of speculation rather than with the entire field. Briefly but concisely the author deals with those movements of overspeculation and depression, or "cycles of speculation," which periodically occur. The causes of these occurrences are explained, and a complete cycle all the way from the crest of prosperity to the ebb of depression and return is traced. Cycles of stock, grain and cotton speculation are separately treated.

In addition, numerous allied matters are discussed, among them being the effect of the increased gold supply, of money conditions, and of political conditions and crops. There is a brief chapter on "undigested securities," another on the indications of crises, the importance of fixed charges, the bank statement, puts and calls, and how to compute the value of rights. The problems discussed are such as frequently confront the speculator and investor as perplexing stumbling blocks.

Gordon, H. L. The Modern Mother. Pp. x, 278. Price, \$2.00. New York: R. F. Fenno \& Co.

The author presents in popular language a thorough, scientific statement of the proper care which should be afforded a normal girl from infancy to motherhood. The work is sane, able, direct and well illustrated. The book represents a notable step in advance in the direction of rational education for girlhood and motherhood. The modern home is not prepared to furnish such education; the school does not furnish it, and the need for books of this character is most urgent.

Grice, Mary V. Home and School United in Widening Circles of Inspiration and Service. Pp. 154. Price, 6o cents. Philadelphia: Christopher Sower Company, Igog.

With notes of introduction and commendation from Commissioner of Education Brown, Martin C. Brumbaugh, Superintendent of Schools in Philadelphia, and Governor Hughes, of New York, Mrs. Grice here presents a working plan for linking the home, the school, the community and the nation. The book is written in an interesting way. The author has gone into suffi- 
cient technical detail on the formation of home and school associations to make the book of great value to those planning such associations.

Griggs, E. H. Human Equipment, Its Use and Abuse. Pp. 73. Price, 50 cents. New York: B. W. Huebsch, 1909.

Guinness, G. Peru: Its Story, People and Religion. Pp. xxiv, 438. Price, \$2.50. New York: F. H. Revell Company, 1909

Miss Guinness has here set forth her personal experiences in missionary work in Peru. She has done a real service in describing minutely the routine of her daily visits to the sick and infirm, and in pointing out the many obstacles to winning the confidence of the natives. The plain, straightfor ward recital gives us some idea of the seemingly hopeless misery of the lower classes. Instead of succumbing to the temptation of broad generalization, the author has wisely limited herself to the recital of her personal experiences in Cuzco, Arequipa, Lima and other cities.

There has been so little attempt to study social conditions in any of the Latin-American countries that students of the subject are thankful for every contribution, for it is becoming increasingly clear that the political systems of these countries cannot be understood until we have made a careful study of their social organization.

This work of Miss Guinness would be of far greater value if she had been able to restrain her strong evangelical tendencies. Throughout the work there is a spirit, not only of criticism, but of bitter opposition to the influence of the Catholic Church. Whenever approaching this phase of the subject the author loses all sense of proportion. She makes no attempt to fathom the historical antecedents which explain the present situation. The individual instances of injustice and oppression have aroused her feelings of resentment to a point which makes this portion of her book, while quite as interesting, far less valuable than her description of social conditions; however, in spite of this, the book will be welcomed by those interested in Latin-American affairs.

Hillier, A. P. The Commonweal-A Study of the Federal System of Political Economy. Pp. xii, I62. Price, \$1.50. New York: Longmans, Green \& Co., Igog.

Knight, E. F. The Awakening of Turkey. Pp. x, 355. Price, \$3.00. Philadelphia: J. B. Lippincott \& Co., Igog.

To write contemporary history is always a difficult task. The story of the Turkish Revolution is so bound up with plot and counterplot that only one who has become familiar with all the local conditions by personal experience can hope to give a picture of the complicated tangle. Mr. Knight's experience as a war correspondent acquainted with Turkey for thirty years has supplied him with material available to but few writers. $\mathrm{He}$ has had access through his friends among the Young Turks to documents and diaries which enable him to trace the revolutionary movement from the beginnings in Geneva to the present time. 
The Turks are the most misunderstood of peoples. Even the massacres attributed to them were committed in greater part by wild frontier tribes, not by the Turks themselves. The instigators were the officers under the Hamidian regime, which in fact, oppressed all classes and by its far-reaching system of espionage spread terror among Mohammedans and Christians alike. In European Turkey also "it needs a strong rule to keep the rival Christian sects from cutting each other's throats-the Turks can provide that rule."

The Sultan's policy of plunder, taken with the conflicting interests of those who hope to become Turkey's heirs, has brought the country to the verge of financial ruin, from which only a thorough-going revolution and the development of the new national spirit can save it. The program of the Young Turks-a strong army, the development of the national resources, reform in taxation and the introduction of responsible representative government-is an extensive one; so extensive that only with great care can it escape failure. Reactionary elements are bound to make the experiment difficult, but Mr. Knight believes it will succeed.

Lanciani, R. Wanderings in the Roman Campagna. Pp. xiii, 378. Boston: Hot.ghton, Mifflin Company, Ig09.

Lichtenberger, James P. Divorce-A Study in Social Causation. Pp. 230. Price, \$r.5o. New York: Longmans, Green \& Co., Igog.

The author examines divorce as a social phenomenon and aims to explain the rationale of our present changing divorce rates. He gives an historical review of the status of divorce and includes representative peoples of both Asiatic and Western civilizations. The statistics of divorce are largely based on the recent census report on that subject. New and interesting tables are, however, abstracted from the census data. The attitude of the Protestant denominations toward the problem, the work of the National Congress on Divorce, legislation and its effect on the increase of divorce, and the economic, social and political conditions which induce its development are ably handled by the author. Special emphasis is laid upon the last subject. The transition from a one-sided matrimonial tie to mutually acceptable monogamic relations is logically accompanied by the severance of ill-formed marital bonds. The emergence of woman from a servile condition to one of measurable independence has made divorce a "cost of progress," but will eventually make matriage an enduring spiritual bond because of the greater equality of rights and the wider range of woman's choice. The divorce era should be followed by one of more stable family relations.

The thesis is strongly written and is highly commendable for its unbiased explanation of the divorce phenomenon. Through a better understanding of the place of divorce in this transition period, much ignorant criticism would be silenced and the way opened for the correction of the abuses that inevitably accompany an ill-directed movement.

Lloyd, H. D. Men, The Workers. Pp. viii, 280. Price, \$1.50. New York: Doubleday, Page \& Co., Igog. 
Marden, P. S. Travels in Spain. Pp. vii, 434. Price, \$3.00. Boston: Houghton, Mifflin Company, 1909.

Books of travel are often little more than diaries, which are of great interest only to the one whose experiences they record. Mr. Marden's work is not of this class. He has a keen appreciation of the picturesque and ability to make what he sees interesting to the reader. There is not a dull page in the book. The journey over which we are taken touches most of the historic monuments of the most composite country of Europe. Entry is made by the south, whence the chief cities up to Burgos, then east to Barcelona, are visited. This omits the southeast coast cities and the Basque provinces, but covers all other points of importance. A chapter on Tangiers hardly needs an apology for its insertion, but for some reason Gibraltar, right on the line of travel, is omitted.

Throughout the journey emphasis is placed on art and architecture. The life of the people is touched upon only occasionally; in fact, Mr. Marden admits that his Spanish is confined to a few phrases, which make it impossible for him to get into real touch with the Spaniard as well as with his country. In justice to Spain also it should be said that the unpleasant features, especially the beggars, are not quite so prominent a part of the national life as they appear to have been in the author's experience. The illustrations and type work of the book are excellent. This is especially true of the pictures of the less known cities, such as Ronda and Segovia-points too often neglected by the hurried tourist.

Modern Corporation Accounting, Documents, Blanks, Etc. Chicago: Powers $\&$ Lyons, 1909 .

Morawetz, V. Banking and Currency Problems in the United States. Pp. I I9. Price, \$1.0o. New York: North American Publishing Company, 1909.

Oppenheim, L. International Incidents for Discussion in Conversation Classes. Classes. Pp. xi, 129. Price, \$1.00. Cambridge: University Press, I909.

Palsito, V. H. (Ed.) Minutes of the Comissioners for Detecting and Defeating Conspiracies in the State of New York. 2 vols. Pp. 836. Albany: State of New York, I909.

This is an excellent printing of the laws passed by New York to repress conspiracies against the state by the loyalists during the Revolution. The activities of the commissioners who were appointed to carry out the laws are the special subject of the volumes. The minutes of their meetings at Albany are presented in extenso and their entire work is presented in a summarized form. There is no attempt to give an estimate of the value of the work done by them, but the documents are presented as material for the use of the historian. The editor is to be congratulated upon the excellent character of the work he has done in making the documents-the most important of which existed heretofore only in manuscript-available to the public. 
Parsons, P. A. Responsibility for Crime. Pp. I94. Price, \$1.50. New York: Longmans, Green \& Co., I909.

This is a thesis embodying the results of personal investigations and of the study of the conclusions of eminent criminologists, and presenting independent theories and principles. For penological purposes, the author reduces the six different classes of criminals to two, and in his formula for crime he endeavors to express in a more precise way the vaguely known relations of personality and external stimuli to crime.

Society is responsible for crime, but a large proportion of criminals are accounted for through hereditary influences in the form of a species of atavism. Alcoholism instead of standing in causal relations to crime is largely the concomitant effect of hereditary weakness. This question is, however, discussed too briefly to be given adequate treatment. Environment is a minor factor and its function is "to give heredity full sway."

The prison and the jury system are aptly criticised and the question of restitution is discussed. The complete restitution advocated by the author would, however, impose certain hardships which at best are of questionable expediency. The extermination of mental and moral defectives should be accomplished by the prevention of their propagation. Existing conditions in regard to method and procedure are criticised not for purpose of wanton destruction, but in order that substitutes may be provided before disaster shall overtake the social system.

The student would feel better satisfied if a constructive program had been more elaborately outlined. The book, however, is written in comparatively popular language, and, it is hoped, will spread the principles which are advocated. Unfortunately the thesis did not undergo the searching criticism of some rhetorician who might have suggested numerous improvements in expression. On the other hand, the monograph has much intrinsic merit. Peabody, F. G. The Approach to the Social Question. Pp. vii, 210. Price,

\$1.50. New York: Macmillan Company, 1909.

"Social stability, like the City of God, must have foundations. Social navigation needs a chart of the course. Much social teaching shows the channel by the wrecks of ventures which have missed it." Hence in the midst of the social unrest of our time, Professor Peabody urges that time will be gained and real progress will be facilitated "in turning briefly from the fascinating occupation of solving the social question to the more modest task of understanding the social question." It is the quest for elements of certainty in the social situation which the writer pursues in this volume. His method is through philosophy to seek to comprehend the unity of the subject; to discover the foundations.

Again, "like the City of God in the Book of Revelation, the social question lies four-square, and toward each front leads a well-traveled road." "The first of these approaches is by the way of social science; the second is by the way of sociology; the third is by the way of economics; the fourth is by the way of ethics." Chapters are devoted to the consideration of the insight to be gained from each approach. The last chapter is devoted to the identification of the spirit and aim of social science and social religion. 
Few recent volumes exhibit such broad and sympathetic insight into the dominant spirit of the times. The book cannot fail to be of great value, especially to that large group of persons who have "the zeal of God" for social betterment and who lack only the "knowledge" to make them efficient workmen in the field of social reform.

Rankin, G. A. An American Transportation System. Pp. xv, 464. Price, \$I.50. New York: G. P. Putnam's Sons, 1909.

Rhodes, J. F. Historical Essays. Pp. viii, 346. Price, \$2.25. New York: Macmillan Company, Igog.

This is a collection of eighteen essays, all but three of which have been published elsewhere. There is a distinct unity to the collection, as all but four essays deal with historical method or with individual historians. As a matter of fact, all these fourteen essays treat of historical writers, for $\mathrm{Mr}$. Rhodes is never abstract or analytical, but always deduces his principles of the science from a study of the exponents of the art. Each essay brings cumulative evidence of the keen interest of Mr. Rhodes in personality, and his capacity of combining warm affection with candid criticism. They therefore afford a criterion for judging his historical work. For example, it is interesting to note the weight he attaches to opinion, a class of fact now so generally disregarded. In spite of the value of his plain and sensible estimates of other historians, the greatest interest is in those essays in which he particularly reveals his own methods. These are: "Newspapers as Historical Sources," "The Profession of Historians," "Who Burned Columbia" and "Edward Gaylord Bourne."

Richardson, N. A. Industrial Problems. Pp. 229. Price, \$1.00. Chicago:

Charles H. Kerr \& Co., Igro.

The "Problems" and "Vital Topics" of modern society are discussed at some length, though without any definite scientific viewpoint other than that furnished by a cursory knowledge of Marxian Socialism. The book contains a large number of isolated cases of individual and corporate wrongdoing. Concentration of wealth, corruption, the unemployed, panics, the work of women and children, degeneracy and several other like topics are treated in separate chapters, but in no case is the material satisfactory. The author's economic theories are not substantiated nor are they generally accepted, and his facts, while in some cases derived from good sources, are often not adequately presented.

Riis, Jacob A. The Old Town. Pp. xiv, 269. Price, \$2.00. New York: Macmillan Company, Igog.

The old town is Ribe, in Denmark, where the author was born and where he spent his boyhood. He writes delightfully about the curious old customs and his quaint townsfolk, though he often lays the same stress upon important facts and unimportant details. There is much sympathy and some humor in his descriptions. The town of Ribe dates back a thousand years and had played its part in history, but at the time of which Mr. Riis writes it was 
slumbering undisturbed by the outside world. The storks built their nests on the roofs of the houses, the watchman went his rounds announcing the time of night by a special song for each hour. The description of the fairs, the Christmas customs and boyish pranks claim our interest. Throughout we catch glimpses of the sweet and simple home life which Mr. Riis knew. The book is dedicated "to all who love the old town and the old friends," but everyone can read and enjoy it. Not the least attractive feature of the book are the sympathetic illustrations by W. T. Benda.

Robbins, E. Clyde (compiled by). Selected Articles on Commission Plan of Municipal Government. Pp. ix, I68. Price, \$1.00. Minneapolis: H. W. Wilson Company, ıgog.

In bringing together the views of city officials and students of municipal government on the operation of the commission system, Mr. Robbins has done a real service, not only to those who are preparing briefs and debates on this subject, but also to the undergraduate student of municipal affairs. The operation of this new system of municipal organization is attracting attention throughout the United States, and there is a movement of public opinion distinctly favorable to its adoption. At the present time the public is seeking light on the subject, and it is through compilations such as are presented in this little volume that the enlightenment of public opinion will be effected.

Roeder, F. Die Naturalienbeschaffung für den Verpflegungsbedarf des bayerischen Heeres. P. 117. Berlin: J. G. Cotta, I909.

Schapiro, J. S. Social Reform and the Reformation. Pp. I6o. Price, \$1.25. New York: Longmans, Green \& Co., Igog.

This monograph aims to "present some of the neglected economic aspects of the Lutheran revolt." It is difficult, however, to believe that this hope has been adequately accomplished. As independent subjects the various chapters present interesting and valuable material. As interrelated parts of a connected thesis, the purpose of which is to show how economic infiuences helped to determine the Protestant reformation, they have failed to realize their ambition.

The monograph gives an account of the economic and legal conditions of Germany at the beginning of the sixteenth century. It gives an interesting sketch of the Peasants' Revolt and the attitude toward the latter taken by Luther. In company with other reformers he is shown to have opposed the demands of the peasant classes.

The remainder of the monograph is concerned with Schemes of Reform. The texts of several of the reform propositions, including the Twelve Articles of the Peasants' Revolt, are set forth in Part II, and form a portion of the body of the thesis. Each of the projects is briefly discussed, but their precise relation to the religious movement is not fully covered. The reader wishes that the subject had been as adequately treated as so ambitious a title would warrant. 
Schenk, F. S. The Sociology of the Bible. Pp. 428. Price, \$1.50. New York: Reformed Church Publication Board, 1909.

The professor of practical theology in the seminary of the Reformed Church at New Brunswick, New Jersey, offers in this volume an interpretation of society which is quite unique. Dr. Schenk is well acquainted with modern writers and recognizes the value of their work. He sees also the great need of studying the society of the Israelites.

To the author the society of the Israelites was different from all others in that it started with a supernatural revelation of God, hence had entirely different development. Recognizing in theory the justification of higher criticism of the manuscripts of the Bible, he nevertheless concludes: "For the sociologist, therefore, whatever may be said of the theologian, the traditional view of the Bible is the easy view, and the higher criticism the difficult one." The method followed is, therefore, the very uncritical use of Biblical material, with the natural result that there is little evidence of the growth of social institutions. Whatever of cruelty existed in human relationships elsewhere was practically non-existent in Israel. The main chapters are devoted to The General Sociology of the Bible; The Kingdom of God or the Particular Society of the Bible; the Kingdom of God in the World.

There is a great opportunity as well as need for a real and thorough analysis of the social development reflected in the Bible. A different method, however, is needed.

Seligman, E. R. A. Principles of Economics. $4^{\text {th }}$ edition. Pp. lii, 710.

Price, \$2.50. New York: Longmans, Green \& Co., I909.

The fourth edition of Professor Seligman's text-book is an enlargment of his earlier editions. The introduction, treating of fundamental concepts and the relation of economics to other sciences, has been given slight revision, but the same point of view is taken and the method of discussion is unchanged. The omission of any chapters on Public Finance is to be commended, for undoubtedly the problems of taxation and public expenditure are too complex to be treated in a brief way. The most valuable part of the book, aside from the logical arrangement of topics, is the highly systematized collection of valuable references and diagrams. These have been brought thoroughly up to date and afford efficient aid in the way of illustrative evidence. The closing chapter on "Poverty and Progress" is both prophetic and optimistic: the prophecy, one of a new and better industrial order; the optimism, that based on the growth of a new and healthy public opinion.

Silburn, P. A. The Colonies and Imperial Defence. Pp. vii, 360. Price, 6s. London: Longmans, Green \& Co., 1909.

Spargo, John. The Marx He Knew. Pp. 86. Price, 50 cents. Chicago: Charles H. Kerr \& Co., Igog.

This is a delightful little character study of the man, Marx. Its form, that of a conversation between an Old Comrade, a contemporary of Marx, and a $(46 \mathrm{I})$ 
Young Comrade of the present day, has enabled the author to tell sympathetically the story of a remarkable career.

Stowell, E. C. Consular Cases and Opinions. Pp. xxxvi, 81r. Washington,

D. C.: John Byrne \& Co., Igog.

In this volume Mr. Stowell has done a great service to students of international law, and has at the same time given us a work which will be of much value to every member of the consular service. The cases have been selected with great care and discrimination from both English and American sources. Of special value is the digest of opinions of the Attorney General of the United States on questions which have not and are not likely to be presented to any tribunal for adjudication. Mr. Stowell's book occupies a unique place in the literature of international law. Neither the British nor the continental jurists have offered to students of the subject a compilation of equal scientific and practical value.

Sullivan, J. J. American Business Law. Pp. xxi, 433. Price, \$1.50. New York: D. Appleton \& Co., Igog.

Villiers-Wardell, J. Spain of the Spanish. Pp. xii, 264. Price, \$r.5o. New York: Imported by Charles Scribner's Sons, Igog.

Unlike most books on Spain this is not a discussion of what the average traveler sees, but it is an attempt to discuss the most important of presentday Spanish activities. Prominence is given to the literary, artistic and general culture aspects of the national life. The material is fresh. The best chapters are on modern literature, the press and Catalonia. One is disappointed to find only a single short chapter on the commerce and industries of the peninsula. The varied provincial life which is so characteristic and so important a part of Spain is altogether unexploited. How the people live still remains for some other writer to show us. There are so many excellent books on the classic art of Spain, and upon its churches and monuments, that the space devoted to these subjects might well have been used to give a near view of the Spaniard himself.

Whetham, W. C., and Catharine D. The Family and the Nation. Pp. viii, 233. Price, \$2.50. New York: Longmans, Green \& Co., 1909.

The book is a scientific statement of the principles of eugenics with particular emphasis upon the question of heredity. The discussion of the decline in the birth rate does not show a thorough knowledge of the modern facts, nor is a satisfactory statement made of the causes of the decline. The distinct contribution which is made in the book is the popularized statement of the Mendelian laws of heredity. These laws are carefully analyzed and made unisually clear by means of charts and diagrams. Following the statement of the Mendelian laws is a thorough discussion of the inheritance of defect and ability. The authors are implicit followers of Francis Galton, holding that ability may be inherited as well as defect. They cite the cases of the judges of England, the Bach family and other wellknown instances of transmitted ability, but they fail to show that the ability thus transmitted is the result of heredity alone. It may well arise $(462)$ 
largely through the effects of early training. The authors are justified in concluding that ability may be transmitted through parenthood, but they fail to show that ability may be transmitted through heredity alone.

The work presents a valuable contribution to the field of eugenics in so far as it involves the Mendelian principles; but, like all works based upon the investigations of Galton, it very much overemphasizes the influence of heredity and underemphasizes, almost to the point of neglect, the influence of environment.

Woolston, H. B. A Study of the Population of Manhattanville. Pp. 159. Price, \$1.25. New York: Longmans, Green \& Co., I9og.

Manhattanville, formerly an independent village, has been absorbed by New York City. It, however, retains certain characteristic conditions which, when properly pictured, give us a study of sociological value. The historical development of the village is followed by an analysis of the population in regard to race, nativity, age, sex and conjugal conditions. Under "Social Temper" the psychical traits and social qualities of the various nationalities are discussed and an attempt to classify them into various types of mind is made. The occupational groups, classification of laborers, wage conditions and other economic data are given, and some very interesting vital statistics are presented. Among these are the facts concerning the height, weight, lung capacity and strength of the pupils of two selected schools within the locality. A chapter on the morement of population is added.

The purpose of the monograph is to make such a survey of this increasingly cosmopolitan group as will make the formulation of a definite constructive program of social education and philanthropic work possible.

Yovanovitch, V. The Near-Eastern Problem and the Pan-German Peril.

Pp. 47. Price, 6d. London: Watts \& Co., I909.

Mr. Yovanovitch argues the cause of the Balkan peoples against Germany and Austria. He believes that Austria has been false to the agreements of the Conference of Berlin, and that in her foreign policy she has become little more than a German province. Germany's plans, it is insisted, are well laid for expansion toward the East. She wishes to become the heir to the "Sick Man of Europe," and by the control of Constantinople to dominate the future traffic between the East and West. Balkan peoples must unite to oppose her advance.

REVIEWS.

Addams, Jane. The Spirit of Youth and the City Streets. Pp. 162. Price, \$1.25. New York: Macmillan Company, Ig09.

With a seriousness comparable to that exhibited in all her contributions to the literature of social betterment, Jane Addams has written this little volume on the subject of play. Who better than she, after her residence of twenty years in one of Chicago's most congested and cosmopolitan quarters, and after the building of Hull House, is fitted to voice the yearning of the city's youth for more normal life conditions? In her indictment of modern 
industry, because of its greater interest in the amassing of money than the making of manhood, the spirit of Carlyle and Ruskin again finds expression.

In six short chapters-Youth in the City, The Wrecked Foundations of Domesticity, The Quest for Adventure, The House of Dreams, Youth in Industry and The Thirst for Righteousness-she has established a point of view at once sympathetic and optimistic which must characterize all efforts at improvement. The difficulties to be overcome are chiefly those of environment and are not to be found in the heart of the city youth. The book will do much good.

To the fascination of the theme the author has added the charm of elegance of style. It is a book which the reader will hesitate to put aside until the last page has been reached.

University of Pennsylvania.

J. P. Lichtenterger.

Baty, T. International Law. Pp. viii, 364. Price, \$2.75. New York: Longmans, Green \& Co., 1909.

Though the title indicates a general treatise, this book is really a series of chapters on sovereignty as the basis of international law. The author finds himself in agreement with but few of the current developments. His criticism is always sharp, his argument precise. The first chapters condemn the principle of obligatory arbitration. The idea of a Supreme Court of the World with a classification of powers as to rank is only "suitable material for undergraduates' essays in political science." Arbitration is a thing to be promoted by cultivating "the force of world-wide public opinion," not by any fanciful judiciary.

Each state must have absolute and equal independence. Its policy in the treatment of foreigners must be left entirely to its own will. All aliens are in a state not by right, but by sufferance. "Sentiment and treaties have gone too far in according a highly privileged position to foreigners." An extended review is then given of the cases involving the so-called rights of foreigners in residence. The criticisms are generally fair, but the author gives a wrong interpretation to the Caroline case. He intimates that the United States denied the right to invade in case of "overwhelming necessity." This is not true; the principle Webster wanted to establish was not individual responsibility for the acts committed, but the duty of the invading state to apologize for the violation of sovereignty, a duty the author recognizes, but which England in $\mathbf{1} \mathbf{8}_{\mathbf{4}} 2$ hesitated to admit. The latter chapters take up the cases where interference has taken place to vindicate violated individual rights. Pacific blockade is roundly condemned. It introduces "an element of anarchy into international affairs. . . No nation can afford to weaken the principle that a state must be free within its borders." The principle of the equality of states should be preserved at all hazards. International relations should be improved by the "most cautious adjustment to the demands of public feeling," but any attempt to legislate a state into observance of rules for which it is not ready will prove disastrous. "Those $(464)$ 
who dream of a United States of the World . . would dethrone science and reason and. . substitute. . brute force.

University of Pennsylvania.

Chester Lloyd Jones.

Butler, Elizabeth B. Women and the Trades, Pittsburg, 1907-08. Pp. 440. Price, \$1.50. New York: Charities Publication Committee, 1909.

This volume, the first of that proposed series of six in which the findings of the Pittsburg Survey will be summarized and set forth for the Russell Sage Foundation, deals, sometimes minutely, at all times closely, with those outward aspects of race origins, occupations, environments, wages, and conditions of social life which appeared of moment and interest to the investigator. It is an inquiry relating to some twenty-two thousand women engaged in the food and tobacco industries, the laundries, the metal and glass and printing and garment trades, and other industries in the city of Pittsburg. Besides the matter of the actual inquiry, the book contains many illustrations, some notes upon the state restrictions upon working hours, an excellent bibliography and a very useful index, together with a large number of tables showing the distribution of the workers in trade groups, the industrial subdivisions of labor, the rates of wages in each group and trade, percentages, and the like, and also considerable data relative to the sanitary conditions of labor and living. These tabular comparisons form not the least part of the work and give evidence of the care and patience of the investigator. With this volume before us, it is now possible to glean some hint of the general methods and lines upon which this investigation has been conducted, and to anticipate somewhat the values which will attach to it. While as a whole the work can scarcely be said to add materially to what was already known in general terms within the trades either by implication or directly, it will have a very distinct value as a compilation, and as a basis for future investigatiors. It may very well be that in the completed series of investigations it will achieve a more definite place, with a greater co-ordination and more emphatic values. This book gives us at least a measure of the problem.

New York.

George D. Hartley.

Dealey, James Q. Sociology. Pp. 405. Price, \$1.50. New York: Silver, Burdett \& Co., rgog.

In this compact and comprehensive volume Professor Dealey has made, as he says in his preface, an "attempt to simplify the teachings of sociology and to show how they may be applied to social problems." $\mathrm{He}$ has before him always the thought that "civilization is made up of the sum total of achievements" either genetic or telic. The author does not mean that social groups always planned out their achievements. "They grew spontaneously, naturally, genetically and were determined by the particular needs and con$(465)$ 
ditions at the time. - . . Achievements came under the stress of material necessity or of a growing mentality seeking means of expression."

Professor Dealey aims to present in Part I the fundamental principles upon which any constructive policy should be based. In the first four chapters he discusses the Place of Sociology among the Sciences, Early Social Development, Achievement and Civilization and Social Psychology. In the following chapters of Part $I$, the development of social institutions, the family, the state, religion, morals and culture is traced from their beginnings.

But progress tends more and more toward conscious achievement. Having arrived at certain fundamental principles of association and development, the author shows how, with telic purpose, society may gradually eliminate ignorance, exploitation, pauperism, crime, intemperance and sexual immorality. Thus society may consciously "accelerate its rate of progress."

The book aims to present the sociological problem as a unit. Some may take issue with the author as to whether much that he has included in his treatment is really sociology at all. This is largely a matter of opinion. At least, he has given the material which seems most necessary for a student who is beginning the study of sociology. The broad field covered has made brevity of statement necessary, which may be regarded sometimes as almost dogmatic, and has precluded a wealth of illustration which must be supplied by the instructor who uses the book as a text. The need of an elementary text in sociology leads us cordially to welcome Professor Dealey's book into the field.

University of Pennsylvania.

R. E. CHADDOCK.

Eastman, F. M. The Law of Taxation in Pennsylvania. 2 vols. Pp. xlvi, I 100. Price, \$12.00. Newark: Soney \& Sage, I909.

Aside from the regular reports of the different states dealing with their individual fiscal affairs, little has been written on state and local taxation prior to 1900. Even at the present time the literature on this subject is more or less crudely arranged or limited in scope. It is therefore a matter of more than usual interest that this is a handy, concise reference to the working of taxation machinery in one of the largest and most prosperous commonwealths of the Union.

Excepting one or two topics, the field is thoroughly covered, including the details of assessment and collection, as well as the particular illustrations of various taxes from which the state derives revenue. The methods and powers of taxation of cities of the different classes receive individual attention. A noteworthy addition to the ordinary scope of the work is made by the insertion of a chapter on the Federal Corporation Tax, which is treated without peroration or explanation, in the same legal and analytic manner as the other subjects. Copious citations are appended and a satisfactory index. No attempt is made to theorize, nor does the style permit of argument. The work is a lucid digest of legislation, designed to aid primarily the lawyer and administrator. But to the layman and taxpayer as well it 
should prove of value both as a careful compilation and as a much-needed source of information on the subject of taxation.

\section{University of Pennsylvania.}

\section{LinN Seiler.}

Enock, C. R. Mexico. Pp. xxxvi, 362. Price, \$3.00. New York: Charles Scribner's Sons, Ig09.

This book on Mexico, its ancient and modern civilization, history and political conditions, topography and natural resources, industries and general development, marks a distinct advance over the author's work, "The Andes and the Amazon." While not attempting a detailed presentation of the history of Mexico, nor an exhaustive description of its political and social institutions, the author has given us an exceedingly readable summary of the historical development of the country, and has supplemented this with a vivid description of life in the rural districts and urban centers.

In his study of social conditions Mr. Enock has made a distinct contribution to the subject. His descriptions show clearly how difficult it is to appreciate the point of view of a people whose history, traditions and racial antecedents are totally different from our own. In many cases the author has wisely contented himself with a mere description of what he has seen without any attempt at interpretation.

In his final chapter the author makes some acute observations on the relation of the United States to the Latin-American countries. He points out that the Monroe Doctrine, which was at first looked upon as a guarantee of Latin-American independence, is now viewed with some distrust, as an attempt on the part of the United States to govern the destinies of her sister republics. He shows how misunderstandings have often arisen not caused by any desire on the part of the United States to dominate her neighbors, but by reason of unfortunately worded despatches and state documents, which to the Latin-American mind create the impression of aggressiveness and ulterior designs of domination.

It is to be hoped that Mr. Enock will further pursue his studies of the Latin-American republics, as his works offer a happy combination of the best type of guide-book and introduction to the study of Latin-American social and political conditions.

Uniz'ersity of Pennsylzania.

L. S. Rowe.

Fagan, J. O. Labor and the Railroads. Pp. 164. Price, \$1.oo. Boston: Houghton, Mifflin Company, rgog.

The thought presented in Mr. Fagan's "Confessions of a Railroad Signalman" has been further elaborated and more fully enforced by citation of concrete instances in this later volume. The author's contention is that railway accidents are due to a lax enforcement of rules governing the $(467)$ 
employees; that this non-enforcement of discipline by superintendents and managers has been brought about by the employees' unions, which have so tied the hands of the railway officials as to deprive them of effective authority over the men. The Interstate Commerce Commission is, furthermore, said to have lessened the protection afforded by the federal safety appliance acts by appointing union men as supervisors to inspect railway equipment and report companies and men that violate the provisions of those laws. The Pennsylvania Railroad is strongly commended for refusing to sign "schedules" (contracts) with the engineers' and firemen's brotherhoods whereby the company's division superintendent's disciplinary authority over the employees would have been minimized.

Mr. Fagan makes a strong presentation of his contention. The advocate of the union schedule would, however, be able to present a strong argument showing the necessity of protecting the employees by means of contracts defining as specifically as possible the obligations of the company and the men. It is certain that the schedule will not be given up. The point raised by Mr. Fagan is, none the less, one that cannot be ignored. If the puublic is to be protected against railway accidents, the unions must not be permitted to throw secrecy about the cat1se of accidents, they must not be allowed to protect their members against the just consequences of their acts; the superintendent and manager must have real authority; and the government must, without fear or favor, give full effect to the safety appliance acts.

\section{University of Pennsylvania.}

EMORY R. JOHNSON.

Hammacher, E. Das philosophisch-ökonomische System des Marxismus. P. 730. Leipzig: Duncker and Humblot, Igog.

That the interest in Marxian socialism continues to the extent that it does in Germany, as well as elsewhere, must be regarded as a recognition of the evergrowing political importance of the socialist movement. The present work is a voluminous one, written by a privat-docent in philosophy at the University of Bonn. The author remarks in his preface, "I have everywhere endeavored to consider socialism as a whole and to indicate its significance as a philosophy of social life interpreted from the historical perspective. In this connection I have also given Proudhon and Rodbertus careful consideration," The socialist might question the utility of the considerable attention accorded to Proudhon. More justifiable are, in a way, the frequent references to Sombart, and more especially to Kautsky; but it must be remembered that the study is one of Marxism and not only or simply of Marx's works.

The book is divided into three main sections; the first dealing with the evolutionary conceptions and their Hegelian and Feterbachian connections; the second being a critical analysis of the materialistic interpretation of history, including a detailed application of such an interpretation to the Grosskapitalismus of our own day, and the future condition of society; the last section being a critique of Marxian economics, special chapters

$$
\text { (468) }
$$


being devoted to the theory of value, of surplus value, of crises, etc. The last chapter discusses "socialism as an ethical necessity." Dr. Hammacher concludes that neither the materialistic interpretation nor the Marxian system of socio-economics can stand the test of criticism. This might, perhaps, be admitted, but certainly it would be conducive to sounder conclusions if the numerous scholarly critics (like Sombart, Tugan-Baranowsky and Hammacher, to refer to a few only) and still more numerous superficial critics could agree, even in a fair measure, as to what parts of Marx must be rejected as untenable, and why. Dr. Hammacher, however, is not to be blamed for not attempting to present the impossible, for, as it is, one may sometimes suspect that an intellectual or economic bias on the part of the critic is the real basis of his criticism.

There are numerous passages throughout the book to which economists of classical tendencies as well as those of more modern schools would object, without regard to the author's final conclusions; but the size of the work precludes more detailed reference to these in this place. The book bears the stamp of sincerity of purpose and of German thoroughness. The fact that the author's aim has been to treat the Marxian system as a unified whole gives it a peculiar value, and the philosopher as well as the economist should find the book useful.

Washington, D. C.

Charles E. Stangeland.

Laughlin, J. Lawrence. Latter-Day Problems. Pp. vi, 302. Price, \$1.50.

New York: Charles Scribner's Sons, I909.

The significance of this volume is conspicuously omitted from its title. It is a collection of essays, some of which have already appeared in current publications on modern economic problems. The first six chapters-The Hope for Labor Unions, Socialism a Philosophy of Failure, The Abolition of Poverty, Social Settlements, Political Economy, and Christianity and Large Fortunes-"deal with methods to be applied for an improvement in the condition of those classes which have the least of this world's goods, and which most appeal to our sympathies and assistance." The remaining chapters-The Valuation of Railways, Guarantee of Bank Deposits, The Depositor and the Bank, Government vs. Bank Issues-deal with technical business management in a limited field of finance.

The book is frankly capitalistic in its spirit and aim, and is a defence of the present system. Remedies for social betterment are shown to lie in the improvement in the moral character of the laborer rather than in the general methods of social production and distribution. Voluntary limitation of the birth rate among the lowest classes will diminish the laborers and consequently raise wages in those groups, while methods of thrift will stimulate savings and enable the workman to join the capitalist class. Labor unions, social settlements and churches find their chief function in raising standards of efficiency and increasing moral stability among the poor. 
The defenders of the capitalistic regime could hardly ask for a more logical and forceful presentation of their principles.

University of Pennsylvania.

\author{
J. P. LiChtENBERGER.
}

Liefmann, R. Beteiligungs- und Finanzierungsgesellschaften. Pp. x, 495.

Price, 12m. Jena: Gustav Fischer, 1909.

This book is a dispassionate study in high finance, and deals with those corporations which issue their own securities in place of the stocks of other corporations. It deals, in a word, with Effektensubstitutionsgesellschaften. These fall into two classes: I, Beteiligungsgesellschaften, or those which acquire the securities of other corporations (which they have not promoted and financed) for any one of the following purposes: (a) to diminish the risks of investment, as in the English investment trust, or (b) as a means of attracting capital which would not be invested directly by the public in the controlled corporations, a form most common in Germany, or (c) for the purpose of controlling the policy of the subsidiary corporations, as in the American holding company; and II, Finanzierungsgesellschaften, which promote and finance the corporations whose stocks they acquire, although they may also have some of the characteristics of the preceding class.

The treatise is not a mantal for information concerning specific corporations, but is intended to be primarily theoretical. After a discussion of the stages of economic evolution and much preliminary definition and distinction, a description is given of the leading forms of these corporations in Germany, the United States, England, France, Belgium and Switzerland, together with a statement of the advantages and disadvantages of each form, with a final chapter on economic policy and theory. The description of foreign corporations will be of most interest to American students, for, although the description of conditions here is illuminating, the material is, for the most part, taken from easily accessible sources.

Washington, D. C.

M. O. LORENZ.

Low, A. Maurice. The American People. Pp. 446. Price, \$2.25. Boston: Houghton, Mifflin Company, Igog.

From Dickens down, Englishmen in general have felt competent to criticise America after a visit of some weeks or months at most. Mr. Low brings a judgment of a different sort. His long residence in America, extending over almost a third of a century, and his superior literary and scholastic attainments make his criticism thorough and valuable.

The psychology of a people is a thing difficult for any writer to portray. Mr. Low believes, however, that it "presents no miracle and is reducible to exact terms. There are no wide gaps to be filled by speculative soaring." $\mathrm{He}$ analyzes the psychology of the thirteen original colonies, basing his arguments largely upon the economic factors influencing their (470) 
settlement. There is an excellent chapter on the influence of the American environment. The Revolution was not a thing of a day. The desire for self-government was unavoidable and was bound to grow, whether the English foreign office had adopted a policy wise or stupid. Englishmen in America naturally became revolutionists.

Massachusetts and Virginia hold the author's attention in a large part of the book. The influence of tobacco culture is especially well brought out, and the connections between South Carolina and rice and cotton growing, between Maryland, Pennsylvania and Rhode Island and religious liberty and between the New England states and commerce, is well emphasized. The discussion of the Puritans and their faith occupies almost half the pages, a division Mr. Low justifies by the great influence the Puritans have exercised not only in America, but on civilization in "all the rest of the world."

It must be admitted that at times the reader feels that the explanations of social phenomena are too easy to be accurate. For example, one doubts whether the carrying of arms in the South is due to the Carolinians' fear of servile revolt. But whatever objections may be raised as to details, the generalizations are usually accurate and give us a fresh view of influences the bearing of which our nearness often leads us to overlook. Mr. Low's work is one which is written in a style which reminds the reader of John Fiske. The discussion is decidedly human; the illustrations are always apt and forceful. The central argument-that America is developing a highly individualistic character, which stamps its people as a new race-is well worked out. The analysis extends in this volume only to the end of the eighteenth century. It is hoped that Mr. Low will continue the work to show the influence of the great formative forces that were introduced by the new immigrations following the Revolution, and the various other economic and political developments that have characterized our national growth.

\section{University of Pennsylvania.}

Chester Lloyd Jones.

Murphy, E. G. The Basis of Ascendancy. Pp. xxiv, 250. Price, \$r.50. New York: Longmans, Green \& Co., Igo9.

Five years ago the "Problems of the Present South," by Mr. Murphy, was hailed as one of the best volumes ever written on the subject. This reputation is maintained in "The Basis of Ascendancy." The style is pleasant, the tone optimistic. It is an appeal to all citizens, North as well as South, to recognize the great significance of the presence of the Negro in America; to realize the far reaching effect upon the character and institutions of whites as well as blacks of the measures adopted; and, above all, to see the possibility of better days ahead.

A southerner himself, the author does not hesitate to repeatedly challenge many of the accepted conventions and decisions of the South. He has little sympathy with proposals to keep the Negro ignorant; nor would he deny the suffrage to those who have shown themselves worthy. "It is idle 
to talk of the fineness of the old-time Negro who was illiterate. $\mathrm{He}$, and the paternalistic conditions which created him, are gone forever. We must train our present Negroes through the churches and the schools because we have nothing else through which to train them." "In the fundamental sense we can no more make a bi-racial division of our civilization than we can make a bi-racial division of the sunshine, the rain, the returning seasons."

Incapacity must not rule or ruin capacity. The violent reaction against the postbellum situation was based on the fear of this. But the policy of evasion turns back on those who employ it. We cannot have one law for the Negro, another for the white withont breaking down all law. "If it is hard to convict a white man of the murder of a Negro, it soon becomes equally hard to convict him of the murder of a white man." In the long run repression of the Negro is impossible-his development must be furthered, not hindered. The time has come for constructive policies.

The Negro race is developing; is finding itself; is becoming self-conscious, self-centered. This integrating force will interest American Negroes in Africa, will open opportunities for large service. So long as despair rules there is little progress. Let hope enter and the race moves forward. To give the Negro great responsibility for his own progress is to steady him.

The strong man, the strong race, is burdened by the weak. Lack of homogeneous population cripples our social institutions. In the South only too often has the local situation caused an eclipse of national policies and interests.

In no uncertain terms are the reconstruction policies condemned-and justly. In this most northern students concur. But the new coercion-the reaction of the South against the Negro is equally unfortunate. Social, race integrity is not threatened by recognition of the civil, political and industrial rights of the Negroes. "No true freedom can retard our freedom." The better spirit of the South must respond to the new situation.

The last chapter, "Ascendancy," is a manly, noble appeal to the South to see the difficulty of to-day in order to realize the hope of to-morrow.

Seldom has it fallen to the reviewer's lot to read pages more accurate in presentation of existing problems; more suggestive of the power of man to surmount his obstacles; or evidencing greater faith in humanity. I can hardly commend the book too highly.

University of Pennsylvania.

Carl Kelsey.

Plehn, Carl C. Introduction to Public Finance, Pp. xv, 480. Price, $\$ 1.75$. New York: Macmillan Company, 1909.

This book, which now appears in its third and revised edition, should prove useful as a description of the field of public finance and as a compendium of the recognized writers on public finance, yet there is scarcely a chapter which does not contain statements which invite challenge. The book is arranged in the usual conventional order of expenditure, revenue, debt and 
administration, although no convincing argument is adduced for the treatment of expenditure in advance of revenue in public economy any more than in private economy. Dr. Plehn is strong in his characterizations of existing methods and practice, but narrow in many of his definitions and classifications. For example, he rejects altogether the distinction between special assessments and fees, even while admitting their striking differences. In another place he concludes that "faculty is the ideal basis of taxation" and may "best be measured by income," yet his advocacy of a multiplex tax system indicates his refusal to accept this "ideal." Again, he brashly calls to witness "the wholesale plunder of the United States treasury for pensions," which would hardly be proper in a text-book, even if true. Dr. Plehn also lets his bias against the protective tariff lead him into several questionable assertions. He has, none the less, condensed an immense amount of valuable information into small compass, and his systematic presentation affords a survey sufficiently thorough to justify it as "an introduction" to the study of public finance.

Omaha, Neb.

Victor Rosewater.

Powell, E. T. The Essentials of Self-Government. Pp. vii, 309. Price, \$1.50. New York: Longmans, Green \& Co., Igog.

Efficient laws to control the choice of the legislature are one of the bases of good constitutional government. The subject treated, the English electoral system is, therefore, one which must interest a large public, especially as English practice has often been pointed to as exemplary. Mr. Powell's excellent analysis and well-thought-out suggestions of reform make this book of great value to all those interested in popular government. The material is about evenly divided between exposition of present conditions and the outline of changes which should be introduced. The latter are so great in number and important that the pros and cons often cannot be discussed in detail, but the critical attitude adopted toward each subject always gives the discussion fairness, even though it is not exhaustive.

The first fifty pages discuss the problem of registration. Annual registers kept by public officials who are to be responsible for omissions should be provided. The tax collectors should aid to see that none escape registration. The author clearly puts too much confidence in the system of practically enforced registration which he outlines. Experiments used elsewhere to force the citizen out of his political indifference have been uniform failures. $\mathrm{He}$ also advocates a shorter registration period; just the opposite of what is now thought best by most writers in this country.

The second division treats apportionment and nomination systems. It is by all means the best part of the book. The discussion of present inequalities of representation is excellent. Numerous tables are given to show the shift of population which has made the value of a vote in some districts when compared with others stand as one to eighteen. Reapportionment should be on the basis of electoral strength, not on population, and 
should take place decennially on the basis of the census. The example of Canada on this point is cited, apparently the author was not acquainted with the far greater experience of the United States. Representatives should be chosen in districts returning five to nine members, the voting should be by the proportional system-the single transferable vote preferred-and the representatives should be subject to recall, for, it is asserted, under our present system, the people must periodically abdicate their sovereignty to the legislature, an argument that recalls Rousseau.

The third and fourth parts of the book discuss the application of a number of reforms to the English electoral system. Among the more important are regulation of candidatures and election expenses, sandwichmen and bill posting, and the public payment of election expenses, salaries for members of parliament and control of the use of election agents. The additions which should be made to the present laws on corrupt and illegal practices are discussed in detail, and a final chapter gives the rules which should surround the actual casting and counting of the votes. Both on account of its vivid portrayal of the present electoral system of England and for its helpful, if far reaching, suggestions for reform, this book is welcome.

University of Pennsylvania.

Chester Lloyd Jones.

Schönheyder, K. Kapitalen som faktor i menneskets virksomhed. Pp. I63. Christiania: H. Aschehoug \& Co., Igog.

Dr. Schönheyder's is one of a series of studies published by the faculty of law at the Norwegian University. In this essay on "capital as a factor in human activity" the author devotes the first part to "capital as a productive factor" and the second to "capital as a social factor." His discussions are often unusually original, and he does not hesitate to suggest, if not fully to develop, new lines of thinking. Special chapters are given to considering the wage fund, the Austrian, the productivity and other theories of value. Schönheyder's general criticism of these theories may be stated to be that some are simply new expressions given to older economic conceptions, and that in general too little attention has been given to actual life (dynamics). The author's treatment of his subject is at times difficult to follow, a fact due no doubt in part to originality in his points of view and the limited space he has given to the elaboration of the same. He concludes his book with the now very generally accepted opinion that "the entirely free development of economic conditions involves serious dangers for society as well as capital, and it will be the task of future economists to aid society in the solution of the problem."

Charles E. Stangeland.

Washington, D. C.

Steiner, E. A. The Immigrant Tide, Its Ebb and Flow. Pp. 370. Price, \$1.50. New York: F. H. Revell Company, rgog.

A rare combination of qualities is found in the author, literary power, knowledge of many languages, disciplined mind, years of constant contact $(474)$ 
with Southeastern Europe, a vast fund of sympathy and great faith in fellowman. The book teems, therefore, with human interest. Real men and women are described in its pages.

Dr. Steiner's earlier work, "On the Trail of the Immigrant," has been recognized as one of the best discussions of the problem. "The Immigrant Tide" is a companion volume, more sketchy in its make-up. Last year Dr. Steiner took a group of young men to Europe to put them in immediate contact with the people that they might be better fitted to deal with them in this country. Many of the chapters are based on the experiences of this expedition.

Beginning with the outbound trip, Dr. Steiner comments on some of the habits of the old American group which frequents Europe and wonders if they do not constitute quite as serious a menace to the country as the new immigrants themselves. Then he tells us of the steerage passengers, their history, their successes and failures, showing us how those who have lost in the struggle here go back home again.

Once landed, we are conducted over Southern and Eastern Europe. Dr. Steiner comments on the rise of wages owing to the emigration of so many laborers to America. He notes the suspicion of the ruling class who feel that the peasants become "uppish" as we say as a result of life here, less satisfied with old conditions, leaders of discontent. He notes, too, the newer standards of living brought back. One cannot escape the conclusion that, in unrealized ways, we are affecting Europe.

Interpreting the culture of the various races, the author makes the reader feel somewhat en rapport with many individuals and families. They become more like men and women-less like despised foreigners. Then he returns to America. He takes us about the country showing the conditionsfrequently bad-under which the immigrants live and work. He notes the tragedies in their lives, the influence on their customs and morals. Everywhere there is an appeal to the better group of Americans to understand the stranger within our gates-to give him fair treatment.

Dr. Steiner has no sympathy with the view that those of Southeast Europe are not quite as good as those from the north. He does not advocate unrestricted immigration: is indeed willing to be even more stringent, but he does deplore the prevalent mistreatment and exploitation. He feels that the church is not doing its duty.

The volume is one of great power and value. It will interest and charm the reader. Its philosophy is an appeal to the best within us-its arguments based on unusually rich experience.

University of Pennsylvania.

Carl Kelsey.

Sumner, Helen L. Equal Suffrage. Pp. xxxvi, 282. Price, \$2.00. New York: Harper \& Bros., Igog.

The author gives in this book an impartial record of the effect of equal suffrage in Colorado. During her two years' study of suffrage in Colorado 
she has gathered together a valuable collection of data from which important conclusions can be drawn as to the actual effects of equal suffrage upon politics, upon legislation and upon the women themselves.

The book is divided into two parts. First, a study of the public opinion of Colorado concerning the facts and effects of twelve years of equal suffrage in that state. Miss Sumner has endeavored here to crystallize public opinion by tabulating the answers to over 1200 question blanks circulated among the men and women of that state, some of whom were favorable and some unfavorable to equal suffrage. The second, and more valuable part, consists of another series of tables giving the ascertainable facts concerning the parlicipation or non-participation of women in politics. By an effective citation of statistics the author shows conclusively that the women who vote in Colorado are of the middle and upper classes. The work is strengthened by telling comparisons with the conditions in other states. The investigation as a whole is careful and thoroughly scientific, and it gives a non-partisan yet conclusive sketch of equal suffrage at work.

Philadclphia.

Nellie Marguerite Seeds Nearing.

Thomas, W. I. Source Book for Social Origins. Pp. xvi, 932. Price, \$4.77. Chicago: University of Chicago Press, Igog.

"The study of savage and prehistoric man is one of the most fascinating and important of the social sciences, and at the same time one of the most esoteric. . . On every score it deserves a wider recognition, and I should be happy if I could assist it to come to its own."

Every careful student realizes the importance of a greater knowledge of the customs, morals, conditions both physical and social, of other people and times. Existing literature is voluminous but scattered, and of great differences in value. Recognizing this, Professor Thomas seeks to put in convenient form some of the best authorities, and to suggest further literature.

The editor's plan is perhaps best shown by a brief analysis in tabular form :

Part I.-The Relation of Society to Geographic and Economic Environment. II 4 pages, 8 papers with 4 pages of comment and 6 of bibliography.

Part II.-Mental Life and Education. 282 pages, Io papers, 2 pages of comment and 14 of bibliography.

Part III.-Invention and Technology. 112 pages, 5 papers, 4 pages of comment and 4 of bibliography.

Part IV.-Sex and Marriage. 97 pages, 6 papers, 4 pages of comment and 5 of bibliography.

Part V.-Art, Ornament and Decoration. I08 pages, 6 papers, 8 pages of comment and 12 of bibliography.

Part VI.-Magic, Religion and Myth. 102 pages, 5 papers, 3 pages of comment and $\mathrm{I} 4$ of bibliography. 
Part VII.-Social Organization, Morals, The State. 120 pages, 7 papers, 3 pages of comment and II of bibliography.

These separate hibliographies are supplemented by a very large general bibliography of fifty-four pages. It is evident that Professor Thomas, aside from the introductory chapter of twenty-four pages and two papers included in the text, has personally contributed little to the make-up of the volume. His comments are briefly explanatory of the significance of the papers or are critical of the methods and statements of the writers. Here his suggestions are excellent.

Many of the best known writers are drawn upon: Ratzel ( 5 times), Howitt (5), Spencer (4), Spencer and Gillen (4), Mason, Westermarck, Pitt-Rivers, Tyler, Morgan, Boas and Thomas ( 2 each), and 17 others for single papers.

The selections are excellent. It is hard to see how they could be improved. The volume is well arranged; the index adequate and satisfactory. It is altogether a most useful volume of great value, particularly in the many schools and libraries poorly equipped in these fields. It should find a place in every library and can be widely used. The reviewer heartily concurs in the almost naive opening sentence of the preface, "This book will be found very interesting if read slowly" and would add-very confusing as to details if read too fast. No one but a master can hastily go through such a mass of evidence without becoming bewildered.

\section{University of Pennsylvania.}

Carl Kelsey.

Thompson, John G. The Rise and Decline of the Wheat Growing Industry in Wisconsin. Pp. 250. Price, 50 cents. Madison: University of Wisconsin, 1909.

In this, the work which Dr. Thompson submitted as a thesis for the degree of Ph.D., the wheat industry of the State of Wisconsin is traced from its beginnings to the present time. Wisconsin affords a unique field, inasmuch as the industry sprang up with unusual rapidity and then suddenly declined. It is pointed out in detail how it spread over a wide area during the years from 1850 to 1870 , and then rapidly and steadily declined.

The causes of this rise and decline are explained. The early rise is attributed to the natural adaptability of the soil, the non-forested condition of the southern and western sections of the state, the availability of markets due to the efforts of the railways, the generous land policy of the government, and the economic and race habits of the early settlers.

The rapid decline is attributed primarily to the movement toward diversified agriculture as favored by the railways, the educational institutions and economic conditions; the fall in price of wheat and rise of railroad rates during the $70^{\prime}$ s and 8o's, and the lack of effective organization among the wheat growers. Diversified agriculture found its foothold in the dairying industry, tobacco, hay, potatoes and grains such as rye, oats and barley. 
Later a renewed specialization appeared in some parts of the state in the form of dairying and tobacco, but the wheat industry continued to decline.

The author unfortunately minimizes the effect of soil exhanstion, which every native of large sections of the state knows to be responsible to no small extent for the decline of the industry in those sections. It is for the same reason that some of the later crops such as oats, rye and potatoes are now declining in certain parts of the state. The effect of wheat bugs is likewise, but briefly mentioned, even though they are directly responsible for the practicable absence of wheat growing in many regions which formerly had a large wheat acreage. Aside from these errors the volume is comprehensive and is a contribution to economic history.

Unizersity of Pennsylvania.

G. G. Huebner.

Washington, Booker T. The Story of the Negro. 2 vols. Pp. xiii, 769. Price, \$3.00. New York: Doubleday, Page \& Co., Igog.

Dr. Washington's writings are always characterized by his boundless faith in the future of his own race; by an enthusiasm which makes obstacles and difficulties but incentives to greater achievement. There is likewise a vein of humor whose richest nuggets are often stories at the expense of the white man. This makes his volumes altogether interesting and stimulating.

In "The Story of the Negro" the author seeks to recount the trials and development of the people in Africa and America. In no sense is it a formal history, but rather an interpretation of the Negro's life.

Beginning with his childish notions of Africa, the general situation there is sketched in broad outline with constant drawing of moral lessons. Then follows a description of conditions under slavery. We are told of the free Negro, of fugitive slaves, of Negro abolitionists and preachers, of early settlements in the North. The first volume ends with an account of the Negro's share in the Civil War.

The second volume contains discussions of such topics as reconstruction; the Negro as a workman and land owner; the rise of professional classes; crime; schools; secret societies; Negro communities and homes; Negro art; Negro women; social and missionary work. Some of the material has been published in magazines, but much is new. A large part is drawn directly from the author's own experience and is so effectively told that the men and women named receive as it were a personal introduction to the reader.

"Few people, black or white, realize that in the Negro race, as it exists to-day in America, we have representatives of nearly every stage of civilization, from that of the primitive African to the highest modern life and science have achieved. This fact is at once a result and an indication of the rapidity with which he has arisen." This rise Dr. Washington seeks to establish by repeated accounts of individuals and groups which have progressed.

"The Story of the Negro" is, therefore, a description of the achievements (478) 
of Negroes, not a statement of the problems created by his presence in America. It is to be highly commended, particularly to all those, white or black, whose faith in the possibility of advance on the part of the Negroes needs to be strengthened.

University of Pennsylvania.

CARL KeLSEY.

Wilson, Woodrow. Division and Reunion, 1829-1909. P. $\mathrm{xx}, 389$. Price,

\$1.25. New York: Longmans, Green \& Co., Igog.

This is a new edition of a deservedly popular and widely used text-book, which was first published in 1893 . The present edition differs from the original one chiefly by bringing the survey of events down to the present time. Some seventy pages of text have been added. This new matter has not been prepared by Dr. Wilson, but by his colleague, Professor Edward S. Corwin. Chapter XIII of the previous edition has been omitted, and two new chapters covering the period from 1877 to 1909 appear, one dealing with "Individual and Economic Changes," the other entitled "The United States as a World Power," treating of our foreign relations since 1898 .

The introductory bibliography has been thoroughly revised, but unfortunately the scheme of revision did not include the text or the bibliographies of the first twelve chapters. Hence a few errors in statement of fact, pointed out by reviews when the work was first published, still appear, and references to the newer works have not been included in these bibliographies.

Professor Corwin should be congratulated for the very successful manner in which he has accomplished a difficult task. He has attained the high standard set by Dr. Wilson both as to scholarship and literary form. With a thorough insight into the tendencies of the period he has contributed a keen analysis and a clear and forcible presentation of the salient facts. His narrative is particularly fair and impartial without the suppression of judgment of men and events. He shows the dominating place that industrial and economic questions have attained in domestic affairs since 1877 . This revision has enhanced the value of a text-book already recognized as the best of its kind for the period covered.

University of Pennsylvania.

Herman V. Ames. 